\title{
Nodular Parenchymal Tissue
}

National Cancer Institute

\section{Source}

National Cancer Institute. Nodular Parenchymal Tissue. NCI Thesaurus. Code C94757.

Normal tissue characterized by the presence of well defined parenchymal nodules. 